\title{
INFEKSI PERIODONTAL SEBAGAI FAKTORRISIKO KONDISI SISTEMIK
}

\author{
Oedijani Santoso
}

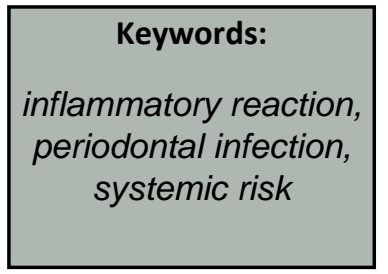

\begin{abstract}
According to Riskesdas 2018 the prevalence of dental and oral diseases in Indonesia is still high (57.6\%) and the most cases are caries and periodontal disease. Periodontal tissue infection is a local oral infection that can be a focal oral infection, and has a risk of affecting systemic conditions. Microorganisms, toxins and inflammatory reactions in infected periodontal tissues can spread systemically to other parts of the body, thatcan cause infections in the area or worsen existing conditions. Systemic conditions that can be affected by periodontal tissue infections including coronary heart disease / arterosclerosis, stroke, diabetes mellitus, pregnancy, chronic pulmonary obstruction, acute respiratory infections. The purpose of this literature review is to refresh about oral focal infection, as well as more convincing that periodontal infection was a risk factor for systemic conditions, in terms of inflammatory reactions.

Influencing inflammatory reactions are inflammatory mediators, including

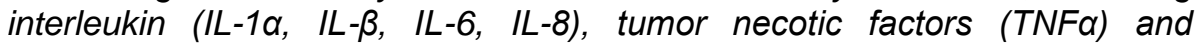
prostaglandin E2 (PGE2). Biological mechanisms support the role of periodontal infection as a potential risk factor for a number of systemic conditions. Future multidisciplinary research should better illustrate the role of periodontal infections in systemic health, so that the influence between periodontal infections and systemic conditions such as premature LBW, diabetes, cardiovascular and cerebrovascular diseases, and respiratory diseases will be increasingly proven
\end{abstract}

\section{PENDAHULUAN}

Menurut Riskesdas 2018 prevalensi penyakit gigi dan mulut di Indonesia masih tinggi $(57,6 \%)$ dan kasus terbanyak adalah karies dan penyakit periodontal. ${ }^{1}$ Infeksi jaringan periodontal merupakan infeksi lokal oral berasal dari mikroorganisme komensal di oral, berkembang biak karena didukung faktor lokal yaitu oral higiene/lingkungan oral buruk ditandai dengan banyaknya plak dan karang gigi. Namun faktor lingkungan, fisik, sosial dan stres yang merupakan faktor sistemik juga mempengaruhi progresivitas penyakit periodontal. Gangguan sistemik seperti fungsi neutrofil, monosit/makrofag, limfosit menyebabkan gangguan aktivitas mediator inflamasi. ${ }^{2-4}$

Konsep fokal infeksi diperkenalkan tahun 1900 oleh William Hunter, seorang dokter Inggris, yang mengembangkan gagasan bahwa mikroorganisme oral ikut bertanggung jawab atas berbagai kondisi sistemik.Penelitian multi disiplin bidang kedokteran dan kedokteran gigi mulai banyak dilakukan, para pakar bidang tersebut

Bagian IImu Penyakit Gigi dan Mulut, Prodi Kedokteran Gigi, Fakultas Kedokteran Universitas Diponegoro, Semarang

Korespondensi: oediyanisantoso@yahoo.com 
sepakat dengan kemungkinan bahwa infeksi fokal oral sebagai faktor risiko terhadap kondisi sistemik, namun masih perlu dilakukan penelitian-penelitian tentang apa dan bagaimana proses penjalarannya dengan pembuktianpembuktian secara biologi molekular. Pada infeksi jaringan periodontal, mikroorganisme dan produknya seperti lipopolisakarida (LPS) masuk ke jaringan periodontal, melewati epitel sulkus yang sering terjadi jejas dan ikut di dalam sirkulasi tubuh. Jaringan periodontal memberikan respon imunoinflamatori terhadap bakteri dan produknya secara lokal, dan secara sistemik juga direspon oleh vaskular mayor.Kondisi sistemik yang dapat dipengaruhi infeksi jaringan periodontal antara lain penyakit jantung koroner/arterosklerosis, stroke, diabetes melitus, kehamilan, penyakit obstruksi paru kronik, infeksi pernafasan akut. ${ }^{5-8}$

Tujuan artikel ini sebagai penyegaran kembali bahwa infeksi bakteri periodontal mempunyai pengaruh tersendiri di rongga mulut danmerupakan faktor risiko kondisi ditinjau dari reaksi inflamasi.

\section{PATOBIOLOGI PERIODONTITIS}

Fokus infeksi adalah infeksi oralyang dapat menyebarkan infeksi ke bagian tubuh lainnya dan berrisiko memperberatkondisi/penyakitsistemik yang sudah adadibagian tersebut. Infeksi oral yang dapat merupakan fokus infeksi antara lain periodontitis, nekrosis pulpa, pulpitis kronis. ${ }^{3-5}$

Trauma kronissaat mastikasi yang diterima gigi dengan periodontitis, menyebabkanbakteri serta hasil reaksi inflamasi pada jaringan periodontal seperti ditekan atau dipompakan masuk ke jaringan yang lebih dalam. Hasil reaksi inflamasi yang ikut menyebar ke jaringan tubuh lain, antara lain interleukin (IL$1 \alpha, I L-\beta, I L-6, I L-8)$, faktor tumor nekosis (TNF $\alpha$ ) dan prostaglandin $\mathrm{E}_{2} \quad\left(\mathrm{PGE}_{2}\right)$. Mediator inflamasiinilah yang akan menyebar keseluruh bagian/organ dan/atau kemungkinan menimbulkan gejala penyakit serta memperparah kelainan yang sudah ada. ${ }^{6-8}$

\section{PENJALARAN FOKAL INFEKSI}

Penjalaran fokal infeksi dapat secara langsung atau per kontinuitatum, yaitu infeksi menyebar langsung dari sumber infeksi ke jaringan atau struktur di sekitarnya misalnya sinusitis, faringitis, tonsilitis. Juga dapat menyebar secara tidak langsung melalui pembuluh darah, pembuluh limfe atau melalui reaksi inflamasi ke organ-organ tubuh lainnya seperti paru-paru, jatung, ginjal dan sebagainya. ${ }^{5,6}$

Perawatan pada gigi dan jaringan penyangga yang merupakan fokal infeksi berupa: skaling, root planning, perawatan endodontik, ekstraksi, odontektomi, dapat menyebabkan bakteremia, serta dapat menyebarkan reaksi inflamasi. Namun penyebaran infeksi hanya pada saat dilakukan tindakan invasif tersebut (ekstraksi $100 \%$, skaling $70 \%$, odontektomi $55 \%$, endodontik 20\%), tidak terus menerus seperti penjalaran infeksi dari fokus infeksi yang tidak dilakukan penanganan.6-8

\section{BARIER ORAL TERHADAP PENETRASI BAKTERI DI RONGGA MULUT}

Beberapa barier oral merupakan daya tahan terhadap penetrasi bakteri ke dalam tubuh. Barier fisik yaitu sel epitel permukaan mukosa, peptida pada mukosa oral, barier elektrik, barier 
imunologi (antibodi) dan barier fagosit (sistem retikuloendotelial). Pada keadaan normal, sistem barier akan bekerja bersama-sama untuk mencegah dan mengurangi penetrasi bakteri. 9,10

\section{MEKANISME PENJALARAN INFEKSI}

Apabila daya tahan tubuh menurun secara sistemik atau terjadi gangguan mikrobial lokal, maka bakteri dan produknya yang merupakan antigen dan faktor virulen (lipopolisakarida =LPS) mengadakan invasi ke sulkus gingiva. Tubuh mengadakan respons imunologik dengan aktivasi sel $B$, sel $T$ dan PMN. Sel epitel yang teraktivasi bakteri dan produknya akan melepaskan mediator inflamasi IL-1, IL-8, PGE2, TNF dan matriksmetaloproteinase (MMP). Hal ini merupakan respons jaringan paling awal terhadap stimuli bakteri, tampak sebagai tanda awal inflamasi jaringan periodontal, dan selanjutnya proses inflamasi periodontitis akan menyebar sistemik ke seluruh tubuh.Tiga mekanisme penjalaran infeksi yaitu bakteremia (metastatic infection), penyebaran toksin (metastatic injury) dan penyebaran reaksi inflamasi (metastatic inflammation). ${ }^{8-10}$
PENYAKIT PERIODONTAL DAN PENYAKIT JANTUNG KORONER (PJK) /ATEROKLEROSIS

Penyakit Jantung Koronermerupakan penyebab kematian di Indonesia dengan prevalensi 1,5\%. ${ }^{1}$ Infark miokardial berhubungan dengan infeksi akut bakteri dan virus, infark biasanya didahului dengan influenza, kemungkinan infeksi oral juga berhubungan dengan infark miokardial. Faktor sistemik yang berpengaruh misal merokok, dislipidemia, hipertensi, DM, tapi pada pasien kadang-kadang belum jelas adanya aterosklerosis koroner. Infeksi lokal menghasilkan reaksi inflamasi kronik yang mendasari PJK. Beberapa studi menyebutkan bahwa periodontitis merupakan awal PJK, maka penelitian ini mendukung konsep bahwa penyakit periodontal merupakan faktor risiko PJK. ${ }^{11,12}$

\section{MEKANISME INFEKSI PERIODONTAL} SEBAGAI FAKTOR RISIKO PJK

Infeksi periodontal berpengaruh pada awal atau progres aterosklerosis dan selanjutnya dapat menyebabkan mekanisme terjadinya PJK. Periodontitis dan aterosklerosis merupakan faktor etiologi kompleks, selain genetik dan pengaruh lingkungan. Periodontitis sebagai faktor risiko dan mempunyai mekanisme yang samadasar patogeniknya. ${ }^{12-13}$

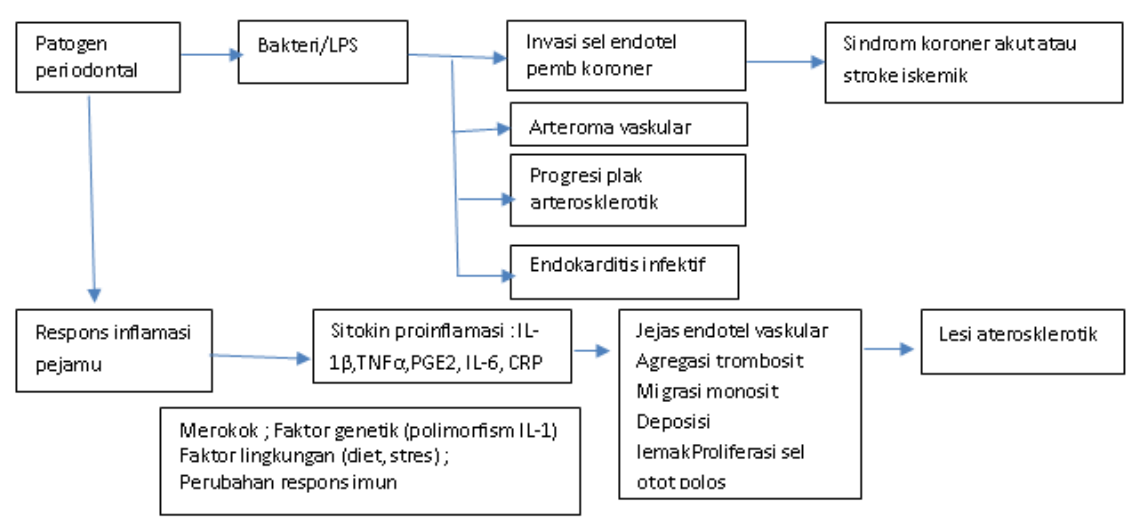

Gambar 1. Pengaruh Periodontitis terhadap PJK 


\section{ATEROSKLEROSIS}

Aterosklerosis adalah penebalan lapisan intima arteri, lapisan paling dalam yang melapisi lumen dan media pembuluh darah, lapisan tebal di bawah intima mengandung otot halus, kolagen dan serat elastik. Awal pembentukan terjadi plak aterosklerotik dikelilingi monosit yang menempel pada endotel vaskular. Pelekatan itu merupakan media beberapa molekul yang mengadakan adesi pada permukaan sel endotelial seperti intercellular adhesion molecule-1 (ICAM-1), endothelialleucocyte adhesion molecule-1 (ELAM-1), dan vascular cell adhesion molecule-1 (VCAM-1). Adesi molekul didukung beberapa faktor seperti LPS bakteri, prostaglandin dan sitokin proinflamatori. Setelah bergabung dengan sel lining endothelial, monosit penetrasi ke endotelium dan migrasi ke bawah intima arteri. Monosit menyerap LDL yang bersirkulasi dalam keadaan teroksidasi dan menjadi membesar, membentuk karakteristik sel busa plak ateromatus. ${ }^{8,13}$

Setelah berada dalam arteri, monosit dapat berubah menjadi makrofag. Kemudian akan diproduksi sejumlah sitokin proinflamasi seperti IL-1, TNFa, PGE2, yang memperbanyak lesi ateromatus. Faktor mitogenik seperti faktor pertumbuhan fibroblas dan faktor pertumbuhan turunan trombosit merangsang otot polos dan proliferasi kolagen sehingga terjadi penebalan dinding arteri.Pembentukan plak ateromatus dan penebalan dinding pembuluh darah mempersempit lumen dan secara drastis mengurangi aliran darah pada pembuluh darah. Trombosis arteri sering terjadi setelah ruptur plak ateromatus. Ruptur plak akanmengaktifkan trombosit dan jalur koagulasi. Akumulasi trombosit dan fibrin membentuk trombus yang dapat menyumbat pembuluh darah, dan mengakibatkan kejadian iskemik seperti angina atau infark miokard. Trombus dapat lepas dari dinding pembuluh darah dan membentuk embolus, yang juga dapat menyumbat pembuluh darah, menyebabkan kejadian akut seperti infark miokard atau infark serebral (stroke). ${ }^{11-13}$

\section{PERAN PENYAKIT PERIODONTAL PADA INFARK MIOKARDIAL ATAU SEREBRAL}

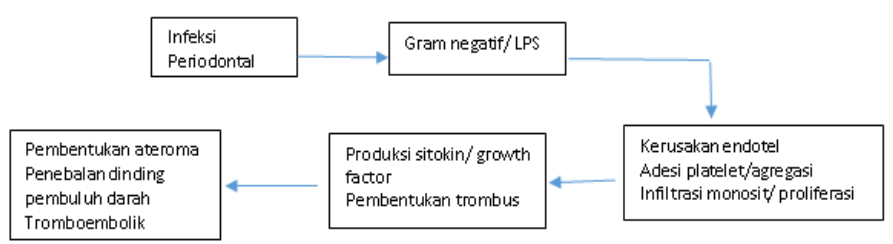

\section{Gambar 2. Pengaruh Infeksi Periodontal terhadap Pembentukan Aterosklerosis}

Pada model binatang, bakteri gram negatif dan LPS menyebabkan infiltrasi sel inflamasi kedalam dinding arteri, proliferasi dalam otot polos arteri, dan terjadi koagulasi intra vaskular. Perubahan ini identik dengan terjadinya ateroma. Studi pada 8 ateroma yang diambil dari endarterektomi, 3 mengandung periodontal patogen. Monosit/makrofag sel lining terlibat pada patogenesis periodontitis dan aterosklerosis. Diet berpengaruh pada peningkatan jumlah LDL serum, mengatur respons monosit/makrofag terhadap LPS bakteri. Peningkatan jumlah LDL merupakan faktor risiko aterosklerosis dan PJK, kemungkinan terjadi peningkatan sekresi destruktif dan sitokin inflamatori dari monosit/makrofag. Hal ini tidak hanya menghasilkan propagasi lesi ateroma tapi juga destruksi periodontal karena adanya organisme patogen. ${ }^{12-14}$ 


\section{PENYAKIT PERIODONTAL DAN STROKE}

Infark iskemik serebral atau stroke sering didahului infeksi sistemik bakteri atau virus. Infeksi merupakan faktor risiko signifikan untuk iskemik serebral, juga faktor risiko lain seperti hipertensi, stroke, merokok, DM, dan PJK. Adanya infeksi sistemik sebelum stroke terjadi iskemik luas dan jejas neurologik pasca iskemik yang berat dibanding tanpa infeksi sistemik. Pasien stroke dengan infeksi, mempunyai jumlah fibrinogen dan CRP lebih tinggi dari pada tanpa infeksi. CRP adalah fase reaktan akut yang cepat meningkat pada keadaan inflamasi dan infeksi. CRP mempengaruhi monosit/makrofag menghasilkan faktor jaringan, dimana terjadi stimulasi pathway koagulasi dan peningkatan fibrinogen. ${ }^{15,16}$

\section{INFEKSI PERIODONTAL PADA HUBUNGAN DENGAN STROKE}

Pada studi kasus-kontrol diketahui bahwa kesehatan gigi yang buruk merupakan faktor risiko iskemik serebrovaskular. 25\% pasien stroke mempunyai infeksi periodontal dibanding kontrol $(2,5 \%)$, mendukung hubungan antara higiene oral buruk dan stroke pada pasien laki-laki umur dibawah 50tahun. Studi lain menyatakan stroke laki-laki dan wanita umur 50 tahun atau lebih mempunyai periodontitis berat dan infeksi periapikal dibanding nonstroke. Banyak kasus stroke disebabkan kondisi tromboembolik dan sebagian karena serebrovaskular aterosklerosis. Infeksi periodontal kontribusi patogenenesis aterosklerosis, dimana bakteri masuk ke endotelium, menyebabkan monosit/makrofag memicu proses inflamasi menghasilkan ateromatosis dan penyempitan lumen pembuluh darah. Infeksi periodontal berhubungan dengan peningkatan plasma fibrinogen dan jumlah CRP dan mendukung terjadinya hiperkoagulasi. Akhirnya bakteri dengan PAAP positif bakteri strain dari plak supra dan sub gingiva menyebabkan peningkatan agregasi platelet, kontribusi pada pembentukan trombus dan tromboebulisme menyebabkan stroke..$^{17-19}$

\section{PENYAKIT PERIODONTAL DAN DIABETES MELITUS}

Sitokin sebagai respons imun seluler yang dihasilkan pada inflamasi periodontal secara sistemik dapat menyebabkan resistensi insulin pasien DM. Studi invitro menyatakan bahwa sitokin bersifat sitotoksik terhadap sel $\beta$ pankreas. Interleukin-1, TNFadan INFY pada konsentrasi kecil bersifat sitotoksik terhadap sel $\beta$ dengan cara menghambat sintesis dan sekresi insulin, tetapi keadaan akan kembali normal dengan hilangnya sitokin. Sitokin bersifat sitosidal jika kadar IL-1 $\beta$, TNFa dan INFY meningkat menyebabkan kerusakan sel pada roden dan manusia. ${ }^{20-23}$

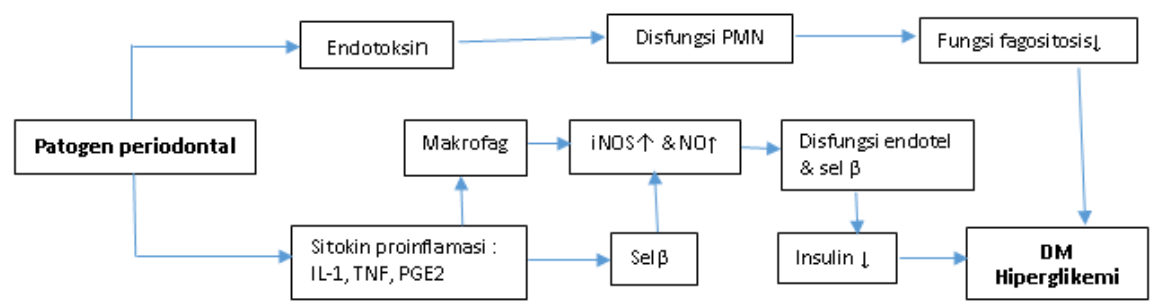

Gambar 3. Skema Inflamasi Jaringan Periodontal terhadap Penyandang DM

ODONTO Dental Journal. Volume 6. Nomor 2. Desember 2019 
Sitokin hasil inflamasi jaringan periodontal terutama IL-1 $\beta$ dan TNF $\alpha$ dapat menyebabkan kerusakan sel $\beta$. Prosesnya melalui 2 mekanisme yaitu menstimulasi ekspresi iNOS (inducible nitric oxide synthase) dan produksi NO (nitric oxide) oleh sel-sel $\beta$, dan stimulasi ekspresi iNOS oleh sel nonendokrin di pulau Langerhans (makrofag dan endotel). Sitokin secara in vitro juga mempengaruhi fungsi reseptor tirosin kinase (reseptor insulin) sebagai katalis langsung reaksi fosforilasi, oleh karena itu sitokin akan mempengaruhi respons seluler yang dihasilkan reseptor insulin misalnya pada transporter glukosa (GLUT4), glikolisis dan sintesis glikogen. Hal ini akan menyebabkan penurunan sekresi insulin pada penyandang DM tipe 2 dengan kelainan periodontal. ${ }^{24-26}$

\section{PENYAKIT PERIODONTAL DAN KEHAMILAN}

Kematian Bayi BBLR neonatal 40 kali dari pada BBLN. $7 \%$ bayi lahir BB < 2500gr dan 2/3 nya meninggal.BBLR akan meningkatkan risiko anomali kongenital, gangguan respiratori, dan disabilitas perkembangan neurologinya, dan untuk perawatannya perlu biaya tinggi. ${ }^{1}$

Penyebab primer kelahiran BBLR adalah ruptur membran prematur. Faktor penyebabnya seperti merokok, alkohol atau pemakaian obatobatan selama kehamilan. Inadekuat perawatan prenatal, ras, status sosial ekonomi rendah, hipertensi, usia ibu hamil terlalu tua atau muda, DM, infeksi saluran genitourinari, meningkatkan risiko BBLR. Namun faktor-faktor tersebut tidak ditemukan pada $1 / 4$ kasus BBLR. Maka banyak penelitian-penelitian tentang hubungan antara infeksi ibu hamil dan kelahiran prematur, ruptur membran prematur, dan BBLR. Tetapi hubungan ini sangat sulit ditemukan karena kebanyakan infeksi ibu hamilsubklinis. Infeksi genitourinari sangat berhubungan dengan outcome kehamilan. Wanita dengan bakteremia mempunyai peningkatan derajad kelahiran preterm dan terapi antibiotik bakteruria menghasilkan penurunan signifikan kelahiran preterm. Peningkatan kolonisasi pada vagina dengan grup B streptokokus atau spesies Bacteroides merupakan risiko ruptur membran prematur pada kelahiran BBLR. ${ }^{27-30}$

\section{PERAN PERIODONTITIS PADA KELAHIRAN BAYI}

Periodontitis merupakan infeksi gram negatif yang berperan pada kejadian BBLR. Pada diskusi terdahulu bahwa organisme periodontopatik dan produknya mungkin memiliki efek rentang yang luas, kemungkinan besar dimediasi melalui stimulasi oleh produksi sitokin pejamu pada target jaringan. Studi dengan hewan coba bahwa dengan adanya reservoir organisme gram negatif dan produknya menyebabkan hal negatif pada kehamilan. $P$. gingivalis yang ada pada subkutan selama kehamilan menyebabkan kenaikan kadar TNFa dan PGE2, dan meningkatkan bayi lahir mati dan menurunkan berat badan lahir. Penurunan berat badan lahir dan peningkatan lahir mati juga terlihat setelah diberikan injeksi intravena LPS dari P. gingivalis. Pemberian injeksi ini lebih terlihat pengaruhnya apabila dilakukan selama kehamilan. P. gingivalis dipakai untuk periodontitis pada model binatang coba dimana menghasilkan penurunan berat badan dan peningkatan tingkat TNF $\alpha$ dan PGE2 pada cairan amnion, ini merupakan bukti bahwa infeksi periodontal mempengaruhi lingkungan fetus dan outcome kehamilannya. ${ }^{30-32}$ 
Studi belah lintang menunjukkan bahwa wanita dengan BBLR mempunyai tingkat $A$. Actinomycetamcomitans, B.forsytus, P.gingivalis, dan T.denticola di plak subgingivalnya dibanding kontrol. Wanita dengan BBLR gingiva, cairan sulkus gingiva (gingival crevicular fluid $=\mathrm{GCF}$ ) nya mengandung PGE2 dan IL-1 tinggi. Tingginya PGE2 dan IL-1 pada GCF berkorelasi dengan tingginya PGE2 dan IL-1 pada cairan intra amnion.
Penilaian mediator inflamasi PGE2 dan IL-1 pada GCF kurang invasif dibanding skrining pada cairan amnion. tinggi dari pada peradangan gingiva, juga jumlah periodontal patogen dan respons terhadap keradangan sub gingiva juga tinggi dibanding wanita dengan BBLN. ${ }^{30-32}$

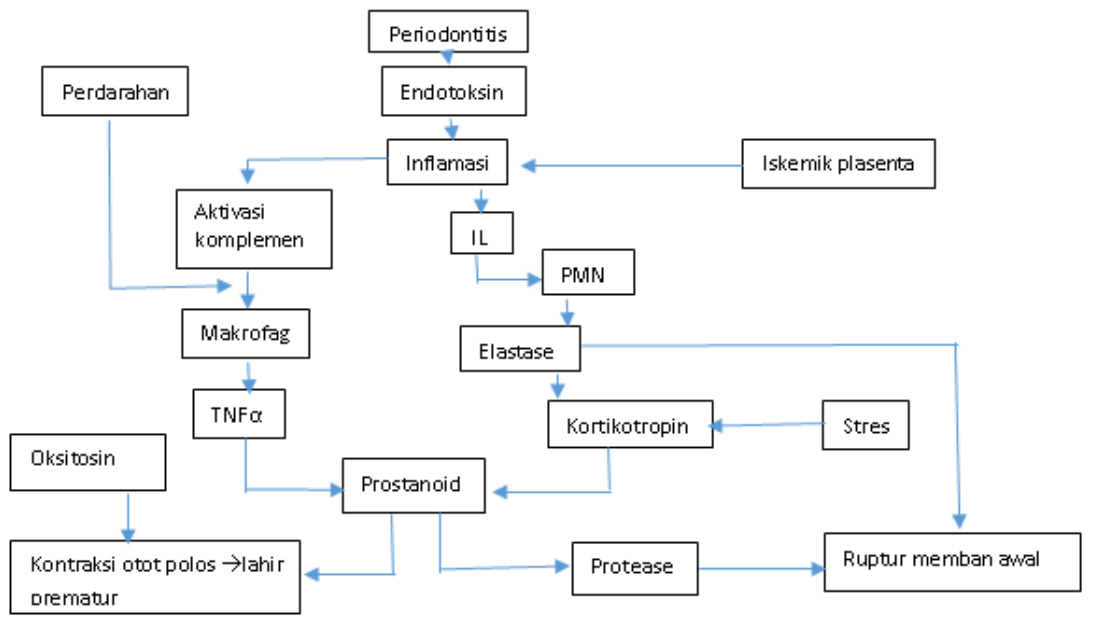

Gambar 4. Pengaruh Periodontitis terhadap BBLR Lahir Prematur

\section{PENYAKIT PERIODONTAL DAN CHRONIC OBSTRUCTIVE PULMONARY DISEASE(COPD = PPOK )}

Penyakit Paru Obstruksi Kronis (PPOK) yaitu penyakit dengan obstruksi jalan nafas karena bronkhitis atau emfisema. Glandula mukosa bronkhial membesar dan terjadi proses inflamasi dimana neutrofil dan sel inflamatori mononuklear terakumulasi didalam jaringan paru.Mekanisme patogenik PPOK hampir sama dengan penyakit periodontal. Pada kedua penyakit ini repons inflamatori pejamu meningkat pada respons perubahan kronik, dengan bakteri pada penyakit periodontal dan faktor merokok sigaret pada PPOK.
Neutrofil influks yang dihasilkanakan melepaskan enzim oksidatif dan hidrolitik menyebabkan destruksi jaringan secara langsung. Berkumpulnya monosit dan makrofag akan melepaskan mediator proinflamasi. ${ }^{6,33}$

Periodontal patogen seperti P. gingivalis, A. actinomycetamcomitans dapat teraspirasi ke paru-paru. Enzim di saliva yang berkaitan dengan penyakit periodontal dapat memodifikasi permukaan mukosa sehingga memudahkan perlekatan dan kolonisasi bakteri patogen. 
Enzim saliva juga dapat menghancurkan pelikel ludah dan pada akhirnya mengurangi perlindungan kekebalan tubuh non spesifik yang melawan patogen respirasi.
Sitokin (IL-1 $\alpha, \quad$ IL-1 $\beta, \quad$ IL-6, IL-8, TNF $\alpha$ ) yang dihasilkan jaringan periodontal dapat mengubah epitel sistem pernafasan dan meningkatkan kerentanan terhadap kolonisasi bakteri patogen, respons inflamasi selanjutnya juga berperan dalam merusak jaringan paru. ${ }^{34-35}$

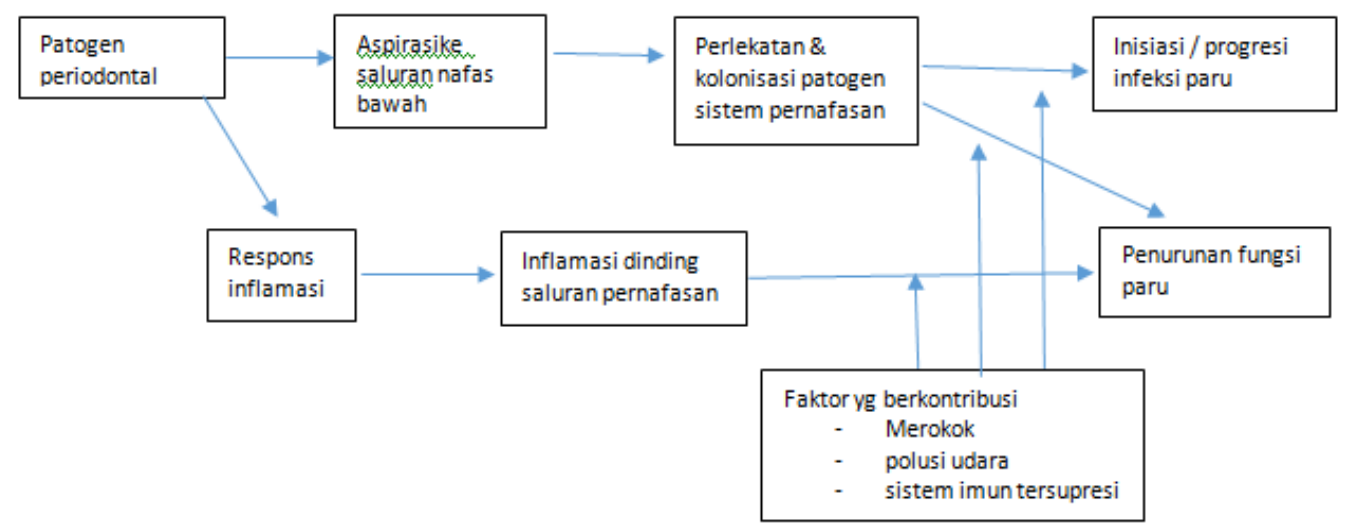

Gambar 5. Pengaruh Periodontitis terhadap PPOK

\section{PENYAKIT PERIODONTAL DAN INFEKSI SALURAN PERNAFASAN AKUT (ISPA)}

ISPA sering kontaminasi dengan organism oral, nasal dan regio faringeal. Sebaliknya saluran bawah biasanya bebas mikroorganisme dengan kombinasi faktor imun pejamu pembersihan mekanis dengan refleks batuk, transport silia dari kontaminan aspirasi dan pergerakan sekresi dari saluran nafas bawahke trachea. Pneumonia adalah infeksi paru yg disebabkanbakteri, virus, fungi, atau mikoplasma dan kemungkinan didapat dari komunitas atau rumah sakit. Banyak variasi bakteri berhubungan dengan pneumonia, dan spektrum organismenya berbeda antara infeksi yang didapat dari komunitas dan infeksi dari rumah sakit. 6,35

\section{PNEUMONIA YANG DIDAPAT DARI KOMUNITAS}

Primer disebabkan inhalasi dari infeksi aerosol atau dengan aspirasiorganisme orofaringeal. S pneumoni dan $H$. influenza paling sering terjadi, tapi beberapa juga dari spesies lain seperti bakteri anaerob. Terapi antibiotik berhasil pada kasus infeksi bakteri pneumonia pada kasus yang didapat dari komunitas. Sampai saat ini dinyatakan tidak ada hubungan antara higiene oral atau penyakit periodontal dan risiko kondisi respiratori akut seperti pneumonia dan individual pneumonia didapat dari komunitas. ${ }^{8,36}$ 


\section{PNEUMONIA BAKTERIAL YANG DIDAPAT DARI RUMAH SAKIT (NOSOKOMIAL)}

Peumonia bakterial derajat morbiditas dan mortalitasnya tinggi, $20-50 \%$ pneumonia meninggal. Insidens pneumonia bakterial tinggi di rawat intensif apalagi didukung pemakaian ventilator. Nosokomial pneumonia biasanya disebabkan aspirasi koloni orofaringeal. Kolonisasi orofaringeal potential respiratory pathogens (PRPs) meningkat selama dirawat dan makin lama dirawat makin banyak PRPs. PRPs juga banyak terdapat pada saluran cerna dan melalui refluks oesofagus masuk ke orofaring dan membentuk koloni, dengan aspirasi menyebabkan pneumonia. ${ }^{4,8}$

PRPs bergabung di oral dengan plak dental sebagai reservoir organisme. Higiene oral yang jelek biasanya didapat pada pasien rawat inap terutama pada sakit yang parah. PRPs banyak ditemukan dengan isolasi plak supragingiva dan mukosa bukal pasien di unit rawat intensif. Organisme tersebut tidak ditemukan rutin pada plak dental tapi kolonisasi plak pada pasien dengan rawat inap lama. Plak subgingiva juga merupakan tempat persembunyian PRPs dan periodontal patogen berhubungan dengan pneumonia nosokomial. Namun, organisme anaerobik pada poket periodontal merupakan inokulum primer penyakit respiratori supuratif seperti abses pulmonari yang mempunyai mortalitas dan mobiditas yang signifikan. Terbukti bahwa periodontal patogen merupakan penyebab infeksi nosokomial pulmonari akut, meski belum ada penelitan yang dipublis tentang peningkatan risiko infeksi dari pasien dengan penyakit periodontal. Begitu juga belum ada penelitian yang mengevaluasi efek perawatan penyakit periodontal pada insidensi pneumonia bakterial. ${ }^{8,36}$

\section{DISKUSI}

Konsep penyakit periodontal hanya berpengaruh lokal pada gigi dan jaringan penyangga harus di revisi, bahwa penyakit periodontal mempunyai efek sistemik. Pada individu yang rentan, infeksi periodontal sebagai faktor risiko penyakit sistemik dan melibatkan mekanisme patogenik dasar pada kondisi tersebut. $^{4}$

Hubungan antara penyakit periodontal dan kesehatan sistemik membutuhkan profesional kedokteran gigi yang mampu memperluas cakrawala, untuk mengenali rongga mulut sebagai salah satu dari banyak sistem organ yang saling terkait.Periodontitis adalah infeksi gram negatif yang mengakibatkan peradangan parah, dengan potensi penyebaran mikroorganisme intravaskular dan produknya ke seluruh tubuh. Namun, periodontitis cenderung menjadi penyakit tanpa keluhan, sampai kerusakan menghasilkan gejala akut. Sebagian besar pasien dan banyak profesional medis tidak mengenali potensi infeksi yang kemungkinan ada di rongga mulut. ${ }^{5-7}$

Edukasi kepada pasien harus merupakan prioritas. Upaya edukasi pasien bidang pengobatan periodontal harus menekankan sifat infeksi periodontal, peningkatan risiko penyakit sistemik yang terkait dengan infeksi, dan peran secara biologik infeksi periodontal pada penyakit sistemik. Demikian juga peningkatan apresiasi terhadap efek potensial infeksi periodontal pada kesehatan sistemik dapat mengakibatkan peningkatan 
permintaan pasien untuk evaluasi jaringan periodontalnya. ${ }^{5,7}$

Peningkatan kesadaran masyarakat mungkin berasal dari surat kabar, majalah, dan sumber awam lainnya. Namun, asal mula informasi yang paling dapat diandalkan adalah profesi dokter gigi dan medis melalui kontak setiap hari dengan pasien. Banyak pasien tidak mengetahui bahwa infeksi periodontal dapat mempunyai efek yang sama dengan infeksi lain secara klinis. Pasien menyerahkan kepada dokter gigi untuk mendiagnosis infeksi periodontal, memberikan perawatan yang tepat, dan mencegah kekambuhan dan atau perkembangan penyakit tersebut. Banyak profesional medis tidak terbiasa dengan rongga mulut dan penelitian kesehatan mulut, maka dokter gigi harus menjangkau komunitas medis dalam upaya meningkatkan perawatan pasien melalui pendidikan dan komunikasi. Demikian juga, pasien harus dididik untuk pencegahan penyakit periodontal,dan pencegahan infeksi periodontal harus dijelaskan dapat menurunkan risiko penyakit sistemik. Sebaiknya dokter gigiharus menekankan langkah-langkah pencegahan pribadi dan komunitas yang berfokus pada kebersihan mulut menyeluruh dan teratur untuk mengendalikan faktor risiko infeksi sistemik karena pengaruh penyakit periodontal. ${ }^{4,6,8}$

\section{KESIMPULAN}

Penyakit periodontal r dapat
meningkatkan risiko gangguan sistemik.
Mekanisme secara biologik mendukung peran
infeksi periodontal pada kondisi ini, tetapi infeksi
periodontal bukan sebagai penyebab tetapi
merupakan risiko kondisi sistemik. Infeksi

periodontal adalah salah satu dari banyak faktor risiko potensial untuk sejumlah kondisi sistemik. Penelitian multidisiplin di masa depan sebaiknya lebih menggambarkan peran infeksi periodontal pada kesehatan sistemik, sehingga hubungan antara infeksi periodontal dan kondisi seperti BBLR lahir prematur, diabetes, penyakit kardiovaskular dan serebrovaskular, dan penyakit pernapasan akan semakin terbukti.

Profesi dokter gigi telah lama mengakui manifestasi kondisi sistemik pada rongga mulut, sekarang dokter gigi harus lebih memahami dampak kondisi periodonsium pada kesehatan sistemik, dan menyebarluaskan kepada tenaga medis yang lain.

\section{DAFTAR PUSTAKA}

1. Riskesdas 2018. Kementrian Kesehatan RI, Jakarta, 2019

2. Osten, DHV, Infeksi fokal (online), (http:/www.scribd.com, diakses April 2018; 2012.

3. I Gusti AA SW. Kerusakan Gigi merupakan fokal infeksi penyebab timbulnya penyakit sistemik, Jurnal Kesehatan Gigi.2013; 1 (1): 1-6

4. Slots J. Periodontology : past, present. Perspectives. Periodontol 2000. 2013; 62: 719

5. Ghali RE. The potential link between periodontal and systemic disease - an overview. JAMR. 2011; 1(1): 24-35

6. Cullinan MP, Ford PJ, Seymour GJ. Periodontal disease and systemic health: current status. Aust Dent J. 2009;54: S62s9.

7. Bansal M, Rastogi S, Vineeth NS. Influence of periodontal disease on systemic disease: 
inversion of a paradigm: a review. Journal of Medicine and Life. 2013; 6(2): 126-30

8. Pizzo G, Guiglia R, Russo LL. Campisi G. Dentistry and internal medicine: from the focal infection theory to the periodontal medicine concept. European Journal of Internal Medicine. 2010; 21(6): 496-502

9. Shangase SL, Mohangi GU, Hassam-Essa $\mathrm{S}$, Wood $\mathrm{NH}$. The association between periodontal and systemic health: an overview. SADJ. 2013; 1(8): 10-2

10. Winning L, Linden GJ. Periodontal and systemic disease. BDJ. 2015

11. Igari $\mathrm{K}$, Kudo $\mathrm{T}$, Toyofuku $\mathrm{T}$, Inone $\mathrm{Y}$, Iwai $\mathrm{T}$. Association between periodontal and the development of systemic disease. Oral Biol Dent. 2014

12. Higashi Y, Goto C, Hidaka T, Soga J, Nakamura S, Fujii Y, Hata T, Idei N, Fujimura $\mathrm{N}$, Chayama K. Oral infection-inflammatory pathway, periodontitis, is a risk factor for endothelial dysfunction in patients with coronary artery disease. Atherosclerosis. 2009;206: 604-10.

13. Yakob M, Söder B, Meurman JH, Jogestrand T, Nowak J, Söder PÖ. Prevotella nigrescens and Porphyromonas gingivalis are associated with signs of carotid atherosclerosis in subjects with and without periodontitis. J Periodontal Res. 2011;46: 749-55.

14. Andriankaja O, Trevisan M, Falkner K, Dorn J, Hovey K, Sarikonda S, Mendoza T, Genco R. Association between periodontal pathogens and risk of nonfatal myocardial infarction. Community Dent Oral Epidemiol. 2011;39: 177-85.
15. Thakare KS, Deo V, Bhongade ML. Evaluation of the C-reactive protein serum levels in periodontitis patients with or without atherosclerosis. Indian J Dent Res. 2010;21: 326-9.

16. Nakajima T, Yamazaki K. Periodontal disease and risk of atherosclerotic coronary heart disease. Odontology. 2009;97:84-91.

17. Reyes L, Herrera D, Kozarov E, Rolda S, Progulske-Fox A. Periodontal bacterial invation and infection contribution to artherosclerotic pathology. J Periodontol. 2013. 84

18. Aarabi G, Eberhard J, Reissman DR, Heydecke G, Seedorf U. Interaction between periodontal disease and artherosclerotic vascular disease-fact or fiction? Artherosclerosis. 2015: 241; 555-60

19. Hosomi N, Aoki S, Matsuo K,et al. Association of serum anti-periodontal pathogen antibody with ischemic stroke. Cerebrovascular Diseases. 2012; 34(5-6): 385-92

20. Preshaw PM. Periodontal disease and diabetes, J Dent.2009; 37: 575-7

21. Neqrato CA, Tarzia O, Javanovic L, Chinellato LE. Periodontal disease and Diabetes mellitus. J Appl Oral Sci. 2013; 21(1): 1-12

22. Ritchie CS. Mechanistic link between type 2 diabetes and periodontitis. J Dent. 2009; 37: $578-9$

23. Lazenby MG, Crook MA. The innate immune system and diabetes mellitus: the relevance of periodontitis? A hypothesis. Clinical Science. 2010; 119(10); 423-9

24. Preshaw PM, Alba AL, Herrera D, Jepsen S, Konstantinidis A, Makrilakis K, Taylor R. Periodontitis and diabetes: a two-way relationship. Diabetologia. 2012;55:21-31 
25. Lakschevitz F, Aboodi G, Tenenbaum H, Glogauer M. Diabetes and periodontal diseases: interplay and links. Current Diabetes Reviews. 2011; 7: 433-9

26. Katagiri S, Nitta $H$, Nagasawa $T$, et al. Effect of glycemic control on periodontitis in type 2 diabetic patients with periodontal disease. J Diabet Invest. 2013; 4(3): 320-5

27. Oedijani-Santoso, Wildam Aditya, Dwi Retnoningrum. Hubungan kebersihan mulut dan gingivitis ibu hamil terhadap kejadian BBLR kurang bulan di RSUP dr Kariadi dan jejaringnya. J M Med Indones. 2009; 43(6): 288-93

28. Madianos PN, Bobetsis YA, Offenbacher $S$. Adverse pregnancy outcomes (APOs) and periodontal disease: pathogenic mechanisms. J Clin Periodontol. 2013; 40: S170-S80

29. Sanz M, Kornman K. Working group 3 of Joint EFPPAPw. Periodontitis and adverse pregnancy outcomes: consensus report of the Joint EFP/AAP workshop on periodontitis and systemic diseases. $\mathrm{J}$ Clin Periodontol. 2013; 40: S164-S9

30. Bansal M, Khatri M, Kumar A, Bhatia G. Relationship between maternal periodontal status and preterm low birth weight. Rev Obstet Gynecol. 2013; 6(3): 135-40

31. Kukkumalla MA, Thomas BS, Pralhadkushtagi, Kaur. Periodontal disease as a risk factor for preterm delivery and low birth weight. J Dent Med Sci. 2014; 13(8): 12-5

32. Lopez NJ, Uribe S, Martinez B. Effect of periodontal treatmenton preterm birth rate: a systematic review of meta-analyses. Periodontol 2000. 2015; 67: 87-130
33. Prasanna SJ. Causal relationship between periodontitis and chronic obstructive pulmonary disease. J Indian Society Periodontology. 2011; 15(4): 359-65

34. Deo V, Bhongade ML, Ansari S, Chavan RS. Periodontitis as a potential risk factor for chronic obstructive pulmonary disease: a retrospective study. Indian J Dent Res. 2009;20:466-470

35. Liu Z, Zhang W, Zhang J, Zhou X, Zhang L, Song $Y$, Wang Z. Oral hygiene, periodontal health and chronic obstructive pulmonary disease exacerbations. J Clin Periodontol. 2012;39:45-52

36. Thanabalan D, Sheeja. Association between periodontitis and respiratory disease-a review. JDent Med Sci. 2014; 13(1): 5-8 